RATKO ZELENIKA, Ph.D.

E-mail: ratko.zelenika@uni-mb.si

University of Maribor, Faculty of Civil Engineering

Smetanova ulica 17, SI-2000 Maribor, Slovenia

TOMAŽ LOTRIČ, M.Sc.

E-mail: tomazlotric@yahoo.com

Združenje šoferjev in avtomehanikov Celje

Slomškov trg 1, SI-3000 Celje, Slovenia

ERVIN BUŽAN, B. Sc.

E-mail: ervin.buzan@siol.net

Gažon 37a, SI-6274 Šmarje, Slovenia
Preliminary Communication Intermodal Transport

Accepted: Oct. 26, 2009

Approved: Dec. 21, 2010

\title{
MULTIMODAL TRANSPORT OPERATOR LIABILITY INSURANCE MODEL
}

\begin{abstract}
Multimodal transportation means transporting goods from a pickup point, where the operator receives the goods, all the way to the delivery location, using at least two different means of transportation, covered under the same multimodal transport contract and by only one document, regardless of the number or type of transportation vehicles used. The key factor to the optimal operation of multimodal transportation is the multimodal transport operator. It is up to this individual to compensate for various unpredictable circumstances, the complexity of the business processes, nature's whims and carelessness. He must also organize and execute multimodal transport in all stages. Due to the above mentioned dangers and the fact that the area of liability insurance for multimodal transport operators is still being neglected, this article raises some valid points in favour of a proposal that would cover all of the transportation means as well as all the accompanying activities with a single insurance policy. The model includes 17 elements of liability insurance for a multimodal transport operator and all values which quantify the insurance elements in 2009 as well as the projected values for 2015, when progress is expected in the areas pertaining to the implementation of economical processes concerning transit development, as well as values for 2025, representing a period of innovation, reconstruction, optimization and modernization. With this supposed model for liability insurance of a multimodal transport operator, the foundation is laid for a liability insurance which would be used by a multimodal transport operator.
\end{abstract}

\section{KEYWORDS}

transport insurance, multimodal transport, multimodal transport operator, multimodal transport operator liability systems

\section{INTRODUCTION}

To ensure the development of international business, one of the key elements is the traffic system, on both national and international levels. In this area, multimodal transportation is gaining importance as a modern means of transporting goods, connecting together almost all traffic branches and transport technologies in international traffic corridors. As such, it represents the most revolutionary rationalization in the context of modern transportation technologies, yet it cannot exist as an individual branch of transport.

Such a rapid technological advancement (which multimodal transportation undoubtedly is) would be impossible without the involvement of a multimodal transport operator that, based on their knowledge and field expertise, would optimally influence the efficiency and risk management in multimodal transportation.

In line with these issues, the following problem has been researched: considering the fact, that for several decades the international multimodal transport and its operator have positively affirmed their existence, there are still no insurance conditions, pertaining to liability insurance of a multimodal transport operator, which implicates several damaging consequences in the traffic industry.

The problem under study has raised the frame for the subject of research as a project: to research and consolidate the relevant characteristics pertaining to transportation and transportation insurance, to analyze and rate the liability system of a multimodal transport operator and to suggest a new insurance model for multimodal transport operators.

The problem and subject define the performance to set the scientific hypothesis: explicit, implicit, disciplinary and multidisciplinary knowledge about techni- 
cal, technological, organization, ecological, economic, legal, ... rules, principles, legalities, transport elements, traffic and transport insurance in general, and especially liability insurance for operators, all create a scientific paradigm to propose a new liability insurance model for multimodal transport operators.

\section{THEORETICAL TRANSPORT AND TRAFFIC CHARACTERISTICS}

\subsection{Concept, importance and types of transport and traffic}

At today's level of development of traffic sciences, especially traffic techniques, traffic technology, organization, economics and law, it would be irrational to analyze all concepts that have been used in the last 50 years both in foreign as well as Slovene literature. As such, it is necessary to systematically present (on both interdisciplinary and multidisciplinary levels) the concept relations between conventional, combined and multimodal transportation and traffic.

\subsection{Important characteristics of conventional transportation and traffic}

Conventional transport is transportation of goods (cargo) from one point to another, with transportation means from only one branch of transport (e.g. by ship, truck, plane, etc.). One key characteristic is that the entire process is covered by one document or contract (e.g. shipping order). Only one organizer (e.g. carrier) organizes such transport.

\subsection{Basic characteristics of combined transport and traffic}

Combined transportation is losing its importance in the field where [5, 28]: (1) the transportation of goods is handled by two different transportation vehicles from two different transport branches, (2) there are as many contracts as there are transport branches and/or transport methods, (3) there are as many documents as there are finalized contracts and (4) the entire transport process can be organized by one or more transport operators.

\subsection{Basic characteristics of multimodal transport and traffic}

The fact that today most of the global theoretical and actual usage, out of all of the aforementioned transport methods, is accounted for by multimodal transport is due to the fact that multimodal trans- port means using at least two different transportation means, both covered by a single regime of a multimodal transport operator $[3,41]$. The characteristics of multimodal transportation are: (1) the multimodal transport operator and receiver of cargo are in two different countries, (2) the cargo transport in the international multimodal transport is done via at least two different transport methods, or that the transport is covered by at least two different transportation branches, (3) the entire international multimodal transport process is covered by one contract signed between the multimodal transport operator and the sender of the cargo, (4) the entire transport process has only one shipping manifest, (5) the entire process is executed and coordinated by a single operator - the multimodal transport operator (MTO). This is usually an international carrier company.

\section{IMPORTANT CHARACTERISTICS OF TRANSPORT INSURANCE}

\subsection{Notion and importance of transport insurance}

Insurance, just like transport insurance, is a legal act, under which the insurer takes full responsibility to cover the insured party for all the damages (insurance fee), which have resulted from the risk which is covered by the insurance contract. The insured party is obligated to pay the insurance cost, known as the insurance premium. This means that insurance in general, as well as the transport kind, is created to maintain an economic balance by negating the economic risks. The transport insurance system encompasses several insurances based on the primary branch of transport: naval insurance, road, railroad and air transport insurance. However, we must not neglect the remaining transport insurances such as: river, mail, telecommunications, pipeline, railway and space transit insurance, combined transport insurance and multimodal transport insurance.

\subsection{Notion and kinds of hull transport insurances}

The hull transport insurance is split into several groups based on the primary branch of transportation: naval, road, railroad and air insurance. Usually the insurance companies only count air and naval insurances as hull insurances. Road and railroad insurances are usually covered under property insurances. Domestic laws only cover the basic insurance contracts; the details and technicalities are left to the insurance companies, so they can accommodate various needs of individual transport branches. 


\subsection{Notions and kinds of cargo transport insurances}

Cargo transport insurance represents the insurance of the goods or cargo during transport. It is split into domestic and international cargo. International cargo covers insurances of goods being imported, exported and re-exported. Domestic cargo covers the insurance of goods that are in domestic transport (within the borders of a given country). The cargo transport insurance is split into several groups based on the primary branch of transportation: naval, road, railroad and air insurance.

\subsection{Carrier liability insurance}

Carrier liability insurance falls under the group of transport insurances where we are unable to find any mention of the said insurance in any nation's laws. As a result, it is usually specified as an insurance contract, under which terms the insurance company will compensate the insurance holder for the damage caused against a $3^{\text {rd }}$ party.

\section{ANALYSIS AND EVALUATION OF MULTIMODAL TRANSPORT OPERATOR LIABILITY SYSTEM}

\subsection{Multimodal operator legal sources}

Compared to other kinds of legal transport regulation, multimodal transport and transport law is still in its growing, developing and affirmative phases and as such does not work as a macro, global and mega legal system. As such it makes sense to present all relevant sources pertaining to multimodal transport in two groups: 1) Primary legal sources of multimodal transport, and 2) Secondary legal sources of multimodal transport.

\subsubsection{Primary legal sources of multimodal transport}

The group of primary legal sources represents the most important international conventions or multilateral legal acts, which contain legal rules and legal institutions for managing legal relationships in conventional, combined and multimodal transportation, such as: 1) UNCTAD [6, 70], 2) International convention equalizing certain rules about loading, agreed upon on 25.8.1924 in Brussels and updated with Protocols in 1968 and 1979 [6, 73], 3) the United Nations convention regarding marine cargo transportation was agreed upon in Hamburg on 31.3.1978 and is known as the Hamburg Rules, became active on 1.2.1992 [6, 75], $4)$ the International marine codex about transporta- tion of dangerous goods (IMDG) from 1977, written in accordance with the rules and institutions of the International Convention on Safety of Life at Sea from 1974 $[6,76], 5)$ the International Convention on the Safety of Life at Sea (SOLAS, 1974) [6, 77], 6) the Convention on international railroad carriage (Fr. Convention aux transports internationaux ferroviaires - COTIF) [6, 83], 7) the Convention on international road carriage (CMR) which regulates the relationships between the international road cargo transport contract parties [6, 96], 8) the European Agreement concerning the International carriage of dangerous goods by road - ADR contains all relevant legal rules about manipulating and transporting dangerous goods by international road transport [6, 97], 9) the Transport International by Road - TIR, Genoa 1959 has special importance in both combined transport, as well as multimodal transport $[6,99]$, and 10) the Convention about the unification of rules pertaining to international airspace (Warsaw Convention - 1929) is used in international transport of passengers and goods with air vehicles $[6,104]$.

\subsubsection{Secondary legal sources of multimodal transport}

The group of secondary legal sources contains the most important national legal acts, which include rules and legal regulations about domestic and international conventional, combined and multimodal transport and traffic, as in the Slovenian legal system: 1) Obligacijski zakonik (OZ) [10], 2) Pomorski zakonik (PZ) [11], 3) Zakon o plovbi po celinskih vodah (ZPCV) [12], 4) Zakon o prevoznih pogodbah $v$ cestnem prometu (ZPPCP-1) [13], 5) Zakon o prevozih v cestnem prometu (ZPCP1) [14], 6) Zakon o prevoznih pogodbah v železniškem prometu (ZPPŽP) [15], 7) Zakon o železniškem prometu (ZZeIP).

\subsection{Classic liability insurance system for multimodal transport operators}

To render the insurance system viable, a contract is needed, with which the operator binds itself to transport the goods via various transportation methods (based in different transport branches), while the party placing the order is bound to pay for the entire transportation.

\subsubsection{Marine operator liability insurance}

A marine operator's liability insurance lies in the legal obligation of the operator, based on the domestic and international legal sources. The operator is responsible for damages, shortages, loss of cargo and delays before handing off the cargo. The operator is not liable if they are able to prove that the cause of the 
damage was beyond anything that could have been planned for and therefore unavoidable.

Considering the fact that a multimodal transport operator can be a marine carrier (VO-MMTO), his limit is considered the responsibility of the ship-owners. Knowing the operator's liability makes it especially important to insure the ship-owners liability. Because insurance companies do not cover some responsibilities and risks under the Common clauses (1992) for FIATA editions for multimodal transport (e.g. Risk of ship collision is only covered $75 \%$ ), ship-owners started forming mutual insurance companies called Protection and Indemnity Clubs to cover the rest. Multimodal marine transport operators who do not have the necessary means can use the Through Transport Mutual Insurance Association - TT Club.

\subsubsection{Road operator liability insurance}

The liability insurance of a road operator usually covers only damages pertaining to the transport contract for which the operator is liable as a carrier. Within the EU, this is covered by the CMR Convention about international road transport, which states that loss of or damage to the cargo must only be repaid up to 8,33 SDR for a $\mathrm{kg}$ of gross weight of the lost or damaged cargo. Beside this, the carrier fee must be returned as well as all other related costs, in full if the cargo was lost or in proportion if the cargo was damaged. Any damage caused by a late shipment must be paid by up to two times the cost of the fare.

\subsubsection{Railroad operator liability insurance}

The liability insurance of a railroad operator covers only the damages specified under the transport contract, if he is the party responsible for the transport. This is covered by the Convention regarding international railroad carriage (COTIF), which Slovenia has signed. The insurance companies do not wish to extend the width of their risk coverage outside of the written norms.

Based on the legal unified liability of the railroad operator in multimodal transport, this type of insurance represents full coverage insurance, since it covers the liability of employees and other third parties involved in the process, as well as all the COTIF norm requirements.

\subsubsection{Aircraft operator liability insurance}

Aircraft liability insurance is heavily dictated in the EU by the European Parliament Decree $785 / 2004 / E S$, which binds the operator to insure each and every flight, regardless of who is the owner of the aircraft or if the flight falls under a special risk category, such as war operations, terrorism, kidnap- pings, sabotage, hostile takeover and public disturbances.

Dictated by the Warsaw Convention, the multimodal operator is liable for any damages, loss or lack of cargo, as well as any delays, unless he can prove that he operated as an attentive operator. Regardless of that, the abovementioned liabilities are usually not covered by a standard aircraft policy, but must instead be insured separately with a special policy or an addendum to the liability policy. The London market offers a policy that covers liability and cargo - The Airline Freight Legal liability and All Risks Wording, LPO 359A (11/82).

\subsection{Network liability system for a multimodal transport operator}

The network liability system binds the multimodal transport operator according to the laws and institutions for the part of transit on which the incident occurred. This means that the multimodal operator is bound by the respective laws depending on which transport branch the accident occurred on: road laws cover the road parts of transport, marine laws the marine parts, etc.

\subsection{Unified liability system for multimodal transport operators}

Under the unified liability system, the operator of multimodal transport is uniformly liable for all possible damages and consequences in a multimodal transport subsystem based solely on a single contract. This means that the operator is responsible for: selection and activities of all involved parties, loss or damage to the cargo and delays from the moment the cargo is picked up to the moment of delivery.

\section{MULTIMODAL TRANSPORT OPERATOR INSURANCE MODEL PROPOSAL}

\subsection{Defining the elements of a universal multimodal transport operator insurance model}

To make a substantiated presentation of a universal model from all interdisciplinary sciences, it is necessary to define all the elements (inputs) with which to assess and form an insurance liability model. The elements are the following: 1) multimodal infrastructure, 2) multimodal superstructure, 3) human potential, 4) financial potential, 5) multimodal information technologies, 6) multimodal transport technologies, 7) multimodal law, 8) business policies of the multimodal 
transport operator, 9) multimodal-transport chains and networks, 10) multimodal-logistics networks, 11) gross domestic product (GDP), 12) multimodal transport ecology, 13) multimodal transport ethics, 14) multimodal transport operator costs, 15) multimodal transport operator service quality, 16) other elements and 17) multimodal transport operator control.

\subsection{Formulating the liability insurance model for a multimodal transport operator}

The relationship between various elements of the liability insurance for a MTO can be effectively presented with a growth matrix. The growth matrix and models based on it follow the economic activities simultaneously via direct and indirect growth stages [4, 481]. The direct stages can be used to express the growth on the activities independently of each other, as well as to show absolute and relative growth speed as well as the relationships between the activities.

Studying the growth matrix helps understand the relationships between the activities, as well as helps coordinate and program them in the future. The time presentations of direct and indirect stages can also show the changes in intensity of activity growth, as well as their structural changes.

It is supposed that the development potential of the liability insurance consists of $n$ mutually dependant elements. We use $y_{i t}$ and $y_{i, t-1}$ to mark the value of the $i$-th element (e.g. input) $(i=1 \ldots n)$ in the period $t$ and $t_{-1}$.

The growth of the input value for element I is:

$$
\Delta y_{i t}=y_{i t}-\Delta y_{i t-1}
$$

The indirect stage of growth of the $i$-th element of liability insurance of the multimodal transport operator with regard to the $j$-th element is defined as a relationship of the $i$-th input growth, $\Delta y_{i t}$, and the value of the $j$-th element in period $t$, or:

$$
r_{i j t}=\Delta y_{i t} / y_{j t} \quad i, j=1, \ldots, n \quad y_{j t} \neq 0
$$

The indirect level of growth can be expressed in the form of a growth matrix of the element values:

$$
R=\left[\begin{array}{cccc}
r_{11} & r_{12} & \cdots & 1_{n t} \\
r_{21} & r_{22} & \cdots & 2_{n t} \\
\vdots & \vdots & \ddots & \vdots \\
r_{n 1 t} & r_{n 2 t} & \cdots & r_{n n t}
\end{array}\right] \quad t=1, \ldots, t .
$$

The elements on the main diagonal $(i=j)$ represent the direct, while the rest represent the indirect levels of growth. The elements in the $i$-th line represent the growth of the input in the $i$-th element of the model. The elements in the $i$-th column represent the growth of the input values in all of the elements in relation to the $i$-th element in period $t$.

In line with what was said, it could be summarized that each element in the matrix is represented by a line and a column, representing the indirect and relative growth relationships. As an example, the first line represents the growth of the first element in relation to the others while the first column represents the growth of the other elements in relation to the first element. The same logic applies across the entire matrix.

The indirect level of growth can be defined with the relationship of the $j$-th element in the $t-1$ period, or

$$
r_{i j t}{ }^{\prime}=\Delta y_{i t} / \Delta y_{j, t-1} \quad i, j=1, \ldots, n .
$$

The connection between the indirect growth level $r_{i j t}=\Delta y_{i t} / y_{j t}$ and $r_{i j t}{ }^{\prime}=\Delta y_{i t} / \Delta y_{j, t-1}$ can be established with the following interconnections:

$$
r_{i j t}=r_{i j t}^{\prime} / 1+r_{j j t}^{\prime} \text { and } r_{i j t}=r_{i j t}^{\prime} / 1-r_{j j t}{ }^{\prime} \quad i, j=1, \ldots, n \text {. }
$$

The external vector of a model element can also define the growth matrix. This way of defining is especially useful in practice. The growth vector of the model elements is defined as:

$$
\Delta y_{i t}=\Delta_{1 t}, \ldots, \Delta y_{m t}
$$

The vector of the reciprocal values of the elements of the model is defined by:

$$
\left(1 / y_{t}\right)=\left(1 / y_{1 t}, \ldots, 1 / y_{n t}\right) \quad y_{i t} \neq 0, i, j=1, \ldots, n .
$$

The external value of the element growth vector and the reciprocal value vector help us define the model growth matrix as:

$$
\begin{gathered}
R_{p t}=\Delta y_{t}^{\prime}\left(1 / y_{t}\right)=\left[\begin{array}{c}
\Delta y_{1 t} \\
\vdots \\
\Delta y_{t n}
\end{array}\right]\left(1 / y_{1 t}, \ldots, 1 / \Delta y_{n t}\right) \\
R_{p t}=\left[\begin{array}{ccc}
\Delta y_{1 t} / y_{1 t} & \cdots & \Delta y / y_{n t} \\
\vdots & \ddots & \vdots \\
\Delta y_{m t} / y_{1 t} & \cdots & \Delta y_{m t} / y_{n t}
\end{array}\right]=\left[\begin{array}{ccc}
r_{1 t} & \cdots & r_{1 n t} \\
\vdots & \ddots & \vdots \\
r_{m 1 t} & \cdots & r_{m n t}
\end{array}\right]
\end{gathered}
$$

When only the direct growth levels are being studied, the growth of individual elements is expressed independently from the growth of others. So, when defining the indirect level of growth, that is the growth of the $i$-th element in relation to the $j$-th $(i, j=1, \ldots, n)$, it is possible to set the structure of the element growth and express all the relations via the matrix in the entire system. At the same time, by expressing the direct and indirect levels, it is possible to follow the intensity changes of the element growth and their structural relations.

\subsection{Assessing the elements of multimodal transport operator insurance model}

Assessing the elements of a multimodal transport operator insurance model based on a sample of transition countries (which include Slovenia) in which the industry of multimodal transport and traffic and transport insurance is lagging behind compared to advanced countries of the European Union.

To assess the elements of the model, we will consider their state and characteristics today, in 2009 and their expected values in 2015, when the EU should 
achieve its final integrity. Improvements are expected in the legal field, as well as a strengthening of economic growth. The values for 2025 are a transparent indicator of a long-term period, where all areas of liability insurance are expected to develop.

\subsubsection{Multimodal infrastructure}

The multimodal infrastructure, as an element of the model, represents an indivisible part of each individual part of the multimodal system, which must operate integrally, complementary and compatibly with similar segments in its field; in a way this creates a synergy within the multimodal system.

The input of multimodal infrastructure grows only with modernization, updating of transport lines and by connecting the transport branches. We expect the input in 2009 to be around 35. Considering that the infrastructure network has great development potential and that the Pan-European corridors will greatly affect the growth necessary for multimodal transportation, we expect this element of the model to have an input of 55 in 2015 and an input of 80 in 2025.

\subsubsection{Multimodal superstructure}

The multimodal superstructure together with multimodal infrastructure represents an indivisible and irreplaceable component in the production of the multimodal service. Keeping in mind the development potential of the multimodal transport operator as an optimization service from the viewpoint of a multimodal superstructure, the quality of service has a high impact on the liability competitiveness and with that on the liability insurance premium.

To make the market role of the multimodal transport operator important, both on the European as well as on the global scale, it is necessary to update and perfect the existing multimodal superstructures, which can be rated with an input of 40 in 2009. In 2015 the input value is estimated at 55 due to the development and interconnection of global logistic operators, and an input of 85 in 2025.

\subsubsection{Human potential}

The human potential as one of the base elements of the model has the characteristic of having very high potential, which unfortunately is not used to its fullest. This can be seen in the education level and lack thereof of the liability insurance.

Considering the fact that the beginnings of transport as well as multimodal transport date far back, the operators still lack the knowledge, experience, expertise and motivation for successful operations [8, 104]. As a result, the input for 2009 is valued at 40 . We expect growth in the near future, due to the general growth of modern transportation, with an input of 60 in 2015 and 90 in 2025.

\subsubsection{Financial potential}

The financial potential is usually represented as a development element of the operator potential. Because of that the operator would be unable to organize, produce and operate the liability insurance, as all monetary flows usually result in transfers of monetary means. Money plays the role of the initial monetary expense of the operator, both for the insurance as well as the execution of its many tasks and payment of current commitments.

To ensure uninterrupted operation of the multimodal transport operator and stay afloat in this turbulent market, the indicators must properly manage: 1) liquidity, 2) indebtedness, 3) activity, 4) economy, 5) profitability and 6) investments. Based on these indicators the financial potential for 2009 has an input of 30 , an input of 55 for 2015 and an input of 80 for 2025.

\subsubsection{Multimodal information technologies}

Multimodal information technologies represent the tools to shape and create the strategies and achieve goals. Even though there is a widespread usage of various technical and technological achievements in the field of information technologies, implanting them into all segments of life, economy and traffic, their usage is still lacking in the multimodal system.

The global multimodal market with developed multimodal subject and a well established adoption of technological achievements from the area of information and communication technologies is showing clear signs that there is a need for new systems which would benefit the information sector of multimodal transport operators. The input for 2009 is 40 , while estimates show an input of 65 for 2015 and 95 for 2025.

\subsubsection{Modern multimodal transport technologies}

Modern transport technologies (containers, RORO, HUCKEPACK) are always considered individually, since changing the branch of transport does not only result in moving the cargo from one transport vehicle to another, but also changing the system [7, 146]. At the same time, it represents a crucial development element of the liability insurance model.

Modern multimodal technologies as a liability insurance element are not used to its fullest and are estimated at an input of 40 for 2009. The goal is to increase their usage, since most international transport includes managing containers. As such, they are already gaining importance and are estimated at an input of 55 for 2015 and 85 for 2025. 


\subsubsection{Multimodal law}

The only existing United Nations Convention about international multimodal transport of goods from 1980, which would be the base (de iure) for legal affairs of multimodal traffic and transport has still not been ratified. By becoming ratified, the Convention would solve many vital questions pertaining to multimodal transport, such as: transport documents, operator and workers, usage of multimodal transport and modern transport technologies in transitional countries and developing countries, etc. However, it is partially already being (de facto) used, as seen in the usage of the FBL-editions for multimodal transport.

The legal regulations concerning multimodal activity are still dependent on unequal legal sources (national, bilateral, multilateral, common terms, usances and customs) of the countries in which the individual multimodal activities are performed. Because the national regulations follow the Convention only loosely, the input for 2009 is rated at 40 . Since a steady development of multimodal law can be expected in the future, the input for 2015 is 55 and 80 for 2025.

\subsubsection{Business policies of multimodal transport operator}

The business policies of multimodal transport operator define the actual goals for a planned period, same as the means, potentials, resources and instruments needed for accomplishing these goals. Goals, which are set in such a manner enable successful flow of operations, growth and development, pointing to a conclusion that it is necessary to merge all policies into a united system by using adequate strategies and structures.

Adjustments of the business policies between the operator, sub-contractor and insurance company, are possible through an adequate strategy and organization structure, to maximize the realization of the liability insurance model, so this element has an input of 40 in 2009. Further development of the liability insurance could result in the business policy of the insurer. It can be expected that in 2015 the input will be 60 and in 2025 it will be 80 .

\subsubsection{Multimodal transport chains and networks}

Multimodal transport chains represent an array of interconnected links or partners and active participants, which enables quick, safe and rational transport service production processes. Because of the high amount of multimodal services, these chains often intertwine, resulting in the formation of multimodal transport networks. The number of different transport connections (roads, railroad lines, air corridors, marine corridors, river channels, oil pipes, gas pipes and the number of transport crossways), which connect the start and end point of cargo and their number constitute the density, length and width (...) of multimodal transport networks.

The increasing integrity of these networks ensures the liability insurance a quick, safe, consistent and rational development. Because of this the input for 2009 is 40 , which will be based on the geographical-transport position in Europe continues to evolve and reach input 60 in 2015 and 85 in 2025.

\subsubsection{Multimodal logistical chains and networks}

Multimodal logistics networks represent one of the key elements of the liability insurance model for multimodal transport operators, which require an interconnected and interdependent network of multimodal logistic centres, traffic lines, corridors, lines (...), multimodal logistic chains, transport chains, transport networks, (...). Based on these factors it allows and represents a safe, quick, rational and efficient liability insurance of a multimodal transport operator.

Considering that by stimulating the development of logistic services and multimodal transportation and by making it the leader in the transport sector of countries in this geographic area, it would be possible to create connections between Pan-European Corridors V and VII (Danube) and Pan-European Corridor VIII (Albania, Greece, Macedonia and Bulgaria) across the axis of Corridor $\mathrm{X}$ axis, by placing several multimodal logistic subjects, thus creating multimodal logistic centres and micro multimodal logistic network. As result this element gets an input 30 for 2009 , by including and developing global processes the need for increasing the efficiency of this element will result in an input of 55 for 2015 and 80 for 2025.

\subsubsection{Gross domestic product}

The gross domestic product is an economic term, marking the most important aggregate of national bills and the most all-encompassing measure of the entire economic activity in a country.

Knowing the data is a prerequisite for the development of both the operator as well as the GDP and with this the shaping of liability insurance for multimodal transport operators. It has to be kept in mind, that the share of calculated gross premium in the gross domestic product, as well as the gross premium per citizen are both important measures, based on which we can anticipate the state of the insurance market in the individual countries. Despite the annual growth and the ever-rising amount of calculated premium, there is still remaining economic potential which is mainly unused. As a result the GDP for 2009 has an input of 45; despite the world crisis the analytics expect the input for 2015 to be 65 and 90 in 2025 . 


\subsubsection{Multimodal ecology}

The ecology in multimodal transport as a basic concept of science as well as activity is that multimodal subject should use their knowledge, abilities and expertise with multimodal activities to promote processes that ensure the creation of "green" services. Just following the necessary technical and legal rules cannot create the ecology of "green" services in multimodal transport; we must presume the usage of economic measures and the evolution of ethical responsibility.

The energy consumption attributed to transport in the $\mathrm{EU}$ is $30.7 \%$, so the input for 2009 is estimated at 40. In the future there will be heavy pressure to take both economical and non-economical steps to stimulate the interest into multimodal transport operators, relying on railroad and marine transport. As result, the input for 2015 is 60 and 85 for 2025.

\subsubsection{Multimodal ethics}

Multimodal transport operator liability insurance requires, in all space and time dimensions, a conscious and constant consideration of ethic principles and ethic rules. Because of that, it is expected from both the operator as well as all contractors of the multimodal transport, that they follow all ethical principles, such as honesty, fairness, mutual respect and especially the operators feeling of responsibility, which is one of the most important principles in multimodal transport, one of the best ways to attract and retain contractors and one of the key factors in insuring the operators' own interests.

Globalization, the growth of information technologies, the competitiveness, informed sellers and buyers all require the operator to maintain a policy of responsible managing, with the highest moral and ethical principles, for which the input for 2009 is 40 . The growth of the operator's standard and that of his contractors, as well as the increased awareness of responsibility will increase the interest in liability insurance for multimodal transport operators. Because of that, the expected input for 2015 is 60 . Further development will ensure an input of 90 for 2025.

\subsubsection{Multimodal transport operator costs}

In theory, as well as in practice, there are various types of costs. The operator of multimodal transport is faced with internal (costs of transport and reloading) and external costs $[2,28]$. External costs have been heavily researched in the EU, trying to find ways of measuring their effects and their financial impact on the inducers. Shifting the costs to the inducers, measuring and charging them, requires a very careful strategy. The European Commission, authorized to distribute EU funds with the intent to encourage com- bined (multimodal) transportation within the MARCO POLO program, considers the external costs of transport mainly based on: incidents, noise, pollution, environmental costs, infrastructure and deadlocks.

The liability insurance costs for a multimodal transport operator are one of the most important factors of managing the company, and as result they directly affect the success of the company. Because of that, the input for 2009 is 40 . With a well-timed, complex and well-organized vision of the operator and insurer, these costs will drop and gain in importance. Because of that, the input for 2015 is 60 and 85 for 2025.

\subsubsection{Multimodal transport operator service quality}

In these times of growing competitiveness, the quality of offered services is becoming a key item of the image and as a result a competitiveness edge, directly affecting the service customers.

Considering that the liability insurance model currently does not treat all elements equally, this element currently only has an input of 40 for 2009. The development of the system is expected to increase the importance of this element, to input 55 in 2015 and 90 in 2025.

\subsubsection{Other elements}

When dealing with liability insurance of a multimodal transport operator, other elements signify: international transport documents, conventions, international transport unions, Fiat and other similar associations of transport and multimodal operators, the world political climate and other factors and resources. Based on this classification, the input for 2009 is 35, estimated at 55 for 2015 and 90 for 2025.

\subsubsection{Multimodal transport operator control}

It is beyond doubt that the efficaciousness and efficiency both increasingly rely on efficient control. Multimodal transport control is a regulated, information-based process, aimed at certain discrepancies between planned and achieved values or at the analysis of the deviation. In a stable market it has the role of a registrar, the role of a navigator in a growing market and the role of the innovator in a market with an above average growth. Multimodal transportation, as an increasingly important efficacy and efficiency field of several business subsystems has to be controlled on two levels: 1) business results - customer satisfaction, operation time, exploitation, operating costs, 2) results of the process - quality, operation time, costs of individual multimodal activities, productivity. Planning without control is irrational, control without planning is impossible, and so the control element has an input of 35 for 2009, 55 for 2015 and 80 for 2025 . 
Table 1 - Multimodal transport operator liability insurance model element values

\begin{tabular}{||l|c|c|c|c||}
\hline \multirow{2}{*}{\multicolumn{1}{|c|}{ Elements }} & \multicolumn{2}{c|}{ Input $y_{i t}$} & Growth \\
\cline { 2 - 5 } & 2009 & 2015 & 2025 & $\Delta y_{i 2025}$ \\
\hline \hline 1. Multimodal infrastructure & 35 & 50 & 80 & 45 \\
\hline 2. Multimodal superstructure & 35 & 55 & 85 & 45 \\
\hline 3. Human potential & 40 & 60 & 90 & 50 \\
\hline 4. Financial potential & 30 & 50 & 80 & 50 \\
\hline 5. Multimodal information technologies & 40 & 55 & 95 & 55 \\
\hline 6. Modern multimodal transport technologies & 40 & 45 & 85 & 45 \\
\hline 7. Multimodal law & 40 & 40 & 80 & 40 \\
\hline 8. Multimodal transport operator business policies & 40 & 40 & 80 & 40 \\
\hline 9. Multimodal transport chains and networks & 40 & 45 & 85 & 45 \\
\hline 10. Multimodal logistic networks & 30 & 50 & 80 & 50 \\
\hline 11. Gross domestic product & 45 & 45 & 90 & 45 \\
\hline 12. Multimodal environment ecology & 40 & 45 & 85 & 45 \\
\hline 13. Multimodal transport ethics & 40 & 50 & 90 & 50 \\
\hline 14. Multimodal transport operator costs & 40 & 45 & 85 & 45 \\
\hline 15. Multimodal transport operator service quality & 40 & 50 & 90 & 50 \\
\hline 16. Other elements & 35 & 55 & 90 & 55 \\
\hline 17. Multimodal transport operator control & 35 & 45 & 80 & 45 \\
\hline
\end{tabular}

\subsection{Shaping multimodal transport operator liability insurance model}

Based on the hypothetical values of the model element quotients, it is possible to determine the growth vector of the current and future values of the elements, in relation to the time period until 2009, until 2015 and until 2025, all shown in Table 1.

The product of growth vector $\Delta y_{2025}$ and the reciprocal values vector of the model $1 / y_{2025}$ determine the matrix of the liability insurance model, in relation to current values (Table 2).

The effects of the liability insurance model are based on the growth matrix. The matrix treats the structural relations of the elements in a specific way: with the help of the matrix it is possible to simultaneously address all of the dependent models and their fluctuations can be studied in a simulated environment via the direct and indirect growth levels. The specificity of the matrix is seen in the fact, that we can express the relations of the different elements, showing the synergic effects of the model. Each row and column express the relation of one element to the others, including the parameters (outputs), which show the direct growth levels and individual effects of the model.

With a model set in place, it is possible to rate its elements and perform tests, so that the achieved results can be sorted according to their synergic effect. This is possible thanks to the direct and indirect growth levels, read from the model. Studying only the direct effects does not offer enough base information about the connections between the model elements.
The direct growth levels represent the independent parameters (inputs) and do not allow changing of the indirect growth relations and interacting alterations. With the set model, a new - theoretical approach is introduced which includes and enables relative changes of elements and connects the elements of the model into a wholesome dynamic approach to liability insurance of a multimodal transport operator.

The research and appraisal of the model elements gives us direct growth levels of the insurance model, as shown in Graph 1 and further explained in the following element results:

Multimodal infrastructure must achieve a growth of $56.26 \%$ in the period between 2009 and 2025, since the Pan European corridors are supposed to be completed in this time, both in Slovenia as well as in the transitional countries. These corridors will enable high quality European transport, logistics and multimodal system, which will in turn enable multimodal operators and transport companies an easier integration into the multimodal market, as well as other global markets. Modern multimodal technologies must achieve a growth of $52.94 \%$ in the period between 2009 and 2025. This is understandable, if we keep in mind that its use is still relatively low. This can be attributed to the lack of transport network connections, services and other deficiencies between the European countries.

Further analysis of the synergic effects of the liability insurance model for multimodal transport operators enables research of the effect of each individual element on the others and their changes in regards to the 


\begin{tabular}{|c|c|c|c|c|c|c|c|c|c|c|c|c|c|c|c|c|c|}
\hline $\begin{array}{l}\text { 咅 } \\
\text { 递 }\end{array}$ & $\begin{array}{l}\stackrel{\circ}{\circ} \\
\stackrel{1}{n} \\
i \\
i n\end{array}$ & 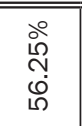 & 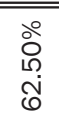 & 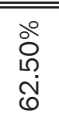 & $\begin{array}{l}\stackrel{\circ}{\circ} \\
\stackrel{\circ}{\circ} \\
\infty \\
0\end{array}$ & $\begin{array}{l}\stackrel{\circ}{\circ} \\
\stackrel{\text { Nิ }}{0} \\
\stackrel{\circ}{\circ}\end{array}$ & 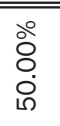 & $\begin{array}{l}8 \\
8 \\
\circ \\
\circ\end{array}$ & 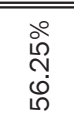 & 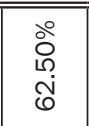 & 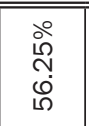 & 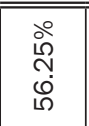 & 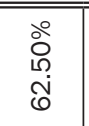 & $\begin{array}{l}\stackrel{\circ}{\circ} \\
\stackrel{\circ}{0} \\
i \\
\llcorner\end{array}$ & 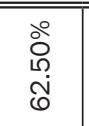 & $\begin{array}{l}\stackrel{\circ}{\circ} \\
\stackrel{\circ}{\circ} \\
\infty \\
0 \\
0\end{array}$ & 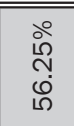 \\
\hline 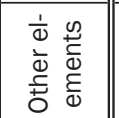 & 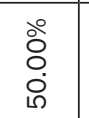 & 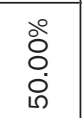 & 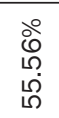 & 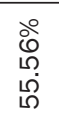 & $\begin{array}{l}\text { में } \\
\text { नें } \\
\text { जे }\end{array}$ & $\begin{array}{l}\text { o̊ } \\
80 \\
\circ \\
\circ\end{array}$ & 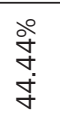 & 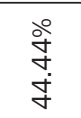 & $\begin{array}{l}\text { o̊ } \\
8 \\
\circ \\
\circ\end{array}$ & 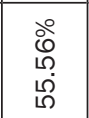 & $\begin{array}{l}\text { oे } \\
\text { oे } \\
\text { in }\end{array}$ & $\begin{array}{l}\text { oे } \\
\text { oे } \\
\text { in }\end{array}$ & 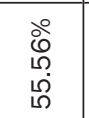 & 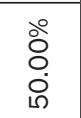 & 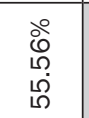 & $\begin{array}{l}\text { बें } \\
\text { नें } \\
\text { षे }\end{array}$ & $\begin{array}{l}\text { o̊ } \\
80 \\
\text { டे }\end{array}$ \\
\hline 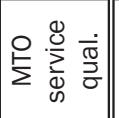 & $\begin{array}{l}\text { o̊ } \\
\text { : } \\
\circ\end{array}$ & $\begin{array}{l}\text { ठें } \\
\text { ०ें } \\
\text { in }\end{array}$ & 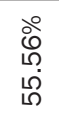 & 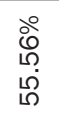 & $\begin{array}{l}\text { วें } \\
\text { नें } \\
\text { षे }\end{array}$ & $\begin{array}{l}\text { ○ें } \\
\text { Оं } \\
\circ\end{array}$ & $\begin{array}{l}\stackrel{\circ}{\stackrel{े}{J}} \\
\dot{J}\end{array}$ & $\begin{array}{l}\stackrel{\circ}{\mathrm{d}} \\
\text { Jं } \\
\dot{f}\end{array}$ & $\begin{array}{l}\text { ठें } \\
\text { ठ். } \\
\text { in }\end{array}$ & 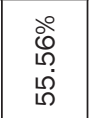 & $\begin{array}{l}\text { ठें } \\
\text { ०ें } \\
\text { in }\end{array}$ & $\begin{array}{l}\text { oे } \\
\text { ०े } \\
\text { in }\end{array}$ & 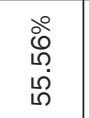 & $\begin{array}{l}\text { oे } \\
\text { Oें } \\
\text { in }\end{array}$ & $\begin{array}{l}\text { i̊ } \\
\text { เి } \\
\text { เి }\end{array}$ & خें & $\begin{array}{l}\text { ठें } \\
\text { ठे. } \\
\text { in }\end{array}$ \\
\hline 옹 & $\begin{array}{l}\stackrel{\circ}{\circ} \\
\text { Oें } \\
\text { Nิ }\end{array}$ & $\begin{array}{l}\text { oे } \\
\text { ஸे } \\
\text { ஸे }\end{array}$ & $\begin{array}{l}\text { ○े } \\
\infty \\
\infty \\
\infty \\
\infty \\
\infty\end{array}$ & $\begin{array}{l}\text { ồ } \\
\infty \\
\infty \\
\infty \\
\infty\end{array}$ & 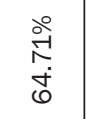 & $\begin{array}{l}\text { oे } \\
\text { ஸें } \\
\text { مิ }\end{array}$ & $\begin{array}{l}\stackrel{0}{0} \\
\dot{\leftrightarrow} \\
\dot{f}\end{array}$ & $\begin{array}{l}\stackrel{\circ}{ } \\
\stackrel{0}{+} \\
\dot{f}\end{array}$ & 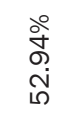 & $\begin{array}{l}\text { ○े } \\
\infty \\
\infty \\
i n\end{array}$ & $\begin{array}{l}\stackrel{\circ}{0} \\
\text { Oें } \\
\text { ஸे }\end{array}$ & $\begin{array}{l}\text { ờ } \\
\text { ஸे } \\
\text { în }\end{array}$ & $\begin{array}{l}\text { مे } \\
\infty \\
\infty \\
\infty \\
i n\end{array}$ & $\begin{array}{l}\text { すे } \\
\text { ஸे } \\
\text { ஸे }\end{array}$ & $\begin{array}{l}\text { مे } \\
\infty \\
\infty \\
i n\end{array}$ & $\begin{array}{l}\stackrel{\circ}{+} \\
\stackrel{+}{+} \\
\dot{0}\end{array}$ & $\begin{array}{l}\text { oे } \\
\text { ஸे } \\
\text { ஸे }\end{array}$ \\
\hline 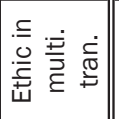 & $\begin{array}{l}\text { oें } \\
\text { ठ̊. } \\
\text { ட. }\end{array}$ & $\begin{array}{l}\text { ठें } \\
\text { ठे. } \\
\text { in }\end{array}$ & 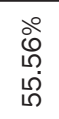 & 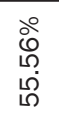 & $\begin{array}{l}\text { วั. } \\
\text { नें } \\
\text { षे }\end{array}$ & 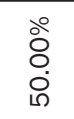 & $\begin{array}{l}\text { 品 } \\
\text { 寸 } \\
\dot{f}\end{array}$ & 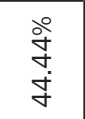 & $\begin{array}{l}\text { वें } \\
\text { ठ். } \\
\text { டे }\end{array}$ & 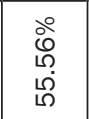 & 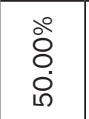 & $\begin{array}{l}\text { ठें } \\
\text { ठें } \\
\text { in }\end{array}$ & 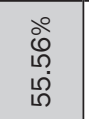 & 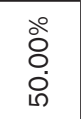 & 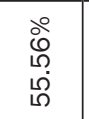 & 守 & $\begin{array}{l}\text { ठें } \\
\text { ठें } \\
\text { in }\end{array}$ \\
\hline 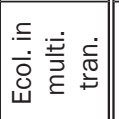 & 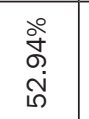 & $\begin{array}{l}\text { ১े } \\
\text { ১े } \\
\text { సે }\end{array}$ & $\begin{array}{l}\text { مे } \\
\infty \\
\infty \\
\infty \\
\infty \\
\infty\end{array}$ & $\begin{array}{l}\text { oे } \\
\infty \\
\infty \\
\infty \\
\infty\end{array}$ & $\begin{array}{l}\text { مे } \\
\text { مे } \\
\text { +े }\end{array}$ & 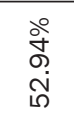 & 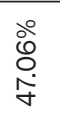 & $\begin{array}{l}\stackrel{\circ}{\circ} \\
\stackrel{8}{0} \\
\dot{+}\end{array}$ & $\begin{array}{l}\text { oे } \\
\text { oे } \\
\text { N่ }\end{array}$ & $\begin{array}{l}\text { مे } \\
\infty \\
\infty \\
\infty \\
\infty\end{array}$ & 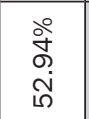 & $\begin{array}{l}\text { ১े } \\
\text { ठे } \\
\text { }\end{array}$ & 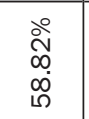 & 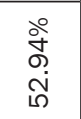 & $\begin{array}{l}\text { مे } \\
\infty \\
\infty \\
\infty \\
\infty \\
\infty\end{array}$ & $\begin{array}{l}\text { के } \\
\text { సे } \\
\dot{0} \\
\end{array}$ & $\begin{array}{l}\text { o̊ } \\
\text { oे } \\
\text { సે }\end{array}$ \\
\hline : & $\begin{array}{l}\text { ठ̊ } \\
\text { ठ̊. } \\
\text { டे }\end{array}$ & $\begin{array}{l}\text { o̊ } \\
\text { òं } \\
\dot{\circ}\end{array}$ & 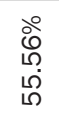 & 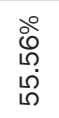 & $\begin{array}{l}\text { नें } \\
\text { नें } \\
\text { षे }\end{array}$ & $\begin{array}{l}\text { ठ̊̊ } \\
\text { ठ். }\end{array}$ & $\begin{array}{l}\stackrel{\circ}{\stackrel{8}{J}} \\
\dot{J}\end{array}$ & 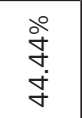 & $\begin{array}{l}\text { ठें } \\
\text { ठ். } \\
\text { in }\end{array}$ & 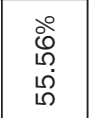 & $\begin{array}{l}\text { ठें } \\
\text { ठें }\end{array}$ & $\begin{array}{l}\text { oें } \\
\text { ठें } \\
\text { in }\end{array}$ & 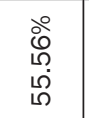 & $\begin{array}{l}\text { ठ̊̊ } \\
\text { : } \\
\text { ட }\end{array}$ & 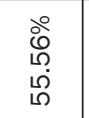 & ㅇํㄹ & $\begin{array}{l}\text { ठें } \\
\text { ठें } \\
\text { in }\end{array}$ \\
\hline ن̀ & $\begin{array}{l}\stackrel{\circ}{\stackrel{\leftrightarrow}{0}} \\
\stackrel{\leftrightarrow}{\circ}\end{array}$ & $\begin{array}{l}\stackrel{\circ}{\stackrel{\leftrightarrow}{0}} \\
\stackrel{\leftrightarrow}{\circ}\end{array}$ & 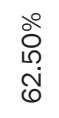 & 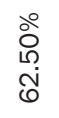 & $\begin{array}{l}\stackrel{\circ}{\circ} \\
\stackrel{0}{\alpha} \\
0 \\
0\end{array}$ & $\begin{array}{l}\stackrel{\circ}{\circ} \\
\stackrel{N}{0} \\
\stackrel{0}{\circ}\end{array}$ & 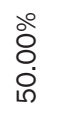 & $\begin{array}{l}\text { oें } \\
\dot{\circ} \\
\text { in }\end{array}$ & $\begin{array}{l}\stackrel{\circ}{\circ} \\
\stackrel{N}{0} \\
\stackrel{0}{\circ}\end{array}$ & $\begin{array}{l}\text { ठें } \\
\text { ஸें } \\
\text { రे }\end{array}$ & $\begin{array}{l}\stackrel{\circ}{\circ} \\
\stackrel{\leftrightarrow}{0} \\
\stackrel{0}{\circ}\end{array}$ & $\begin{array}{l}\stackrel{\circ}{\circ} \\
\stackrel{\leftrightarrow}{0} \\
\stackrel{\circ}{\circ}\end{array}$ & 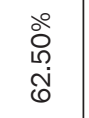 & $\begin{array}{l}\stackrel{\circ}{\stackrel{\leftrightarrow}{0}} \\
\stackrel{\leftrightarrow}{\circ} \\
\llcorner\end{array}$ & 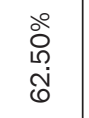 & $\begin{array}{l}\stackrel{\circ}{\circ} \\
\stackrel{2}{\infty} \\
\infty \\
0\end{array}$ & $\begin{array}{l}\stackrel{\circ}{0} \\
\stackrel{\leftrightarrow}{N} \\
\stackrel{0}{\circ} \\
\llcorner\end{array}$ \\
\hline 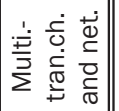 & 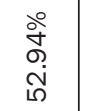 & 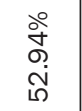 & $\begin{array}{l}\text { oे } \\
\infty \\
\infty \\
\infty \\
\infty\end{array}$ & $\begin{array}{l}\text { Oे } \\
\infty \\
\infty \\
\infty\end{array}$ & $\begin{array}{l}\stackrel{\circ}{\stackrel{े}{+}} \\
\dot{+}\end{array}$ & $\begin{array}{l}\text { oे } \\
\text { ণें } \\
\text { ํํ }\end{array}$ & $\begin{array}{l}\stackrel{\circ}{0} \\
\stackrel{+}{+} \\
\dot{f}\end{array}$ & $\begin{array}{l}\stackrel{\circ}{\circ} \\
\stackrel{+}{+}\end{array}$ & $\begin{array}{l}\text { oे } \\
\text { ஸे } \\
\text { ஸे }\end{array}$ & $\begin{array}{l}\text { مे } \\
\infty \\
\infty \\
\infty \\
\infty\end{array}$ & $\begin{array}{l}\stackrel{\circ}{\circ} \\
\text { ণे } \\
\text { مे }\end{array}$ & 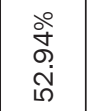 & $\begin{array}{l}\circ \\
\infty \\
\infty \\
\infty \\
\infty\end{array}$ & 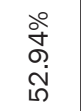 & $\begin{array}{l}\text { مे } \\
\infty \\
\infty \\
\infty \\
i\end{array}$ & $\begin{array}{l}\stackrel{\circ}{\stackrel{े}{+}} \\
\dot{+}\end{array}$ & 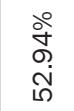 \\
\hline & $\begin{array}{l}\stackrel{\circ}{\circ} \\
\stackrel{\circ}{0} \\
i \\
\stackrel{\circ}{\circ}\end{array}$ & 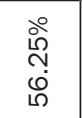 & 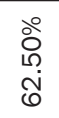 & 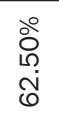 & $\begin{array}{l}\stackrel{\circ}{\circ} \\
\stackrel{\circ}{\infty} \\
\infty \\
0\end{array}$ & 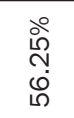 & $\begin{array}{l}\text { oे } \\
\text { ठे. } \\
\text { in }\end{array}$ & 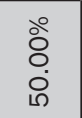 & 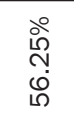 & $\begin{array}{l}\text { 今े } \\
\text { ஸे } \\
\text { రิ }\end{array}$ & $\begin{array}{l}\stackrel{\circ}{\circ} \\
\stackrel{\leftrightarrow}{0} \\
\stackrel{\circ}{\circ}\end{array}$ & $\begin{array}{l}\stackrel{\circ}{\circ} \\
\stackrel{\leftrightarrow}{0} \\
\stackrel{\circ}{\circ}\end{array}$ & 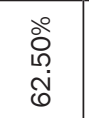 & 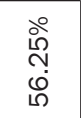 & 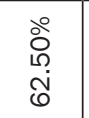 & $\begin{array}{l}\text { ○े } \\
\stackrel{\circ}{\circ} \\
\infty \\
0 \\
0\end{array}$ & $\begin{array}{l}\text { iे } \\
\stackrel{\leftrightarrow}{0} \\
\stackrel{\leftrightarrow}{\circ}\end{array}$ \\
\hline & 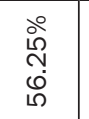 & 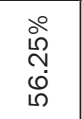 & 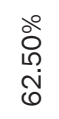 & 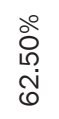 & $\begin{array}{l}\stackrel{0}{\circ} \\
\stackrel{\circ}{\circ} \\
\infty \\
0\end{array}$ & 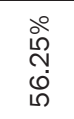 & $\begin{array}{l}\text { ठें } \\
\text { ठ } \\
\text { ஜी }\end{array}$ & $\begin{array}{l}\text { oे } \\
\text { òं } \\
\text { ம் }\end{array}$ & $\begin{array}{l}\stackrel{\circ}{\circ} \\
\stackrel{\text { N }}{0} \\
\stackrel{\circ}{\circ}\end{array}$ & $\begin{array}{l}\text { Oें } \\
\text { مी } \\
\text { ஸे }\end{array}$ & 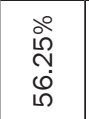 & 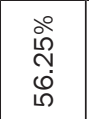 & $\begin{array}{l}\text { oें } \\
\text { م⿱ } \\
\text { ஸे }\end{array}$ & $\begin{array}{l}\stackrel{\circ}{\circ} \\
\text { ஸे } \\
0 \\
\llcorner\end{array}$ & $\begin{array}{l}\text { Oें } \\
\text { ठn. } \\
\text { ஸे }\end{array}$ & $\begin{array}{l}\stackrel{\circ}{\circ} \\
\stackrel{\circ}{\circ} \\
\infty \\
0\end{array}$ & 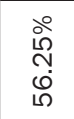 \\
\hline 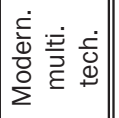 & 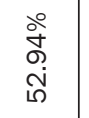 & $\begin{array}{l}\stackrel{\circ}{\circ} \\
\text { ஸे } \\
\text { î }\end{array}$ & $\begin{array}{l}\stackrel{0}{0} \\
\infty \\
\infty \\
\infty \\
\infty\end{array}$ & $\begin{array}{l}\stackrel{0}{ } \\
\infty \\
\infty \\
\infty \\
\infty\end{array}$ & 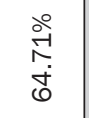 & 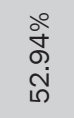 & $\begin{array}{l}\stackrel{0}{0} \\
\stackrel{8}{+} \\
\dot{f}\end{array}$ & $\begin{array}{l}\stackrel{\circ}{\circ} \\
\stackrel{+}{+}\end{array}$ & 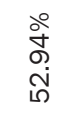 & $\begin{array}{l}\stackrel{0}{ } \\
\infty \\
\infty \\
\infty \\
\infty\end{array}$ & 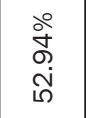 & 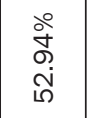 & $\begin{array}{l}\text { ○े } \\
\infty \\
\infty \\
\infty \\
\infty\end{array}$ & $\begin{array}{l}\stackrel{\circ}{\circ} \\
\stackrel{े}{i ் ~} \\
\text { ஸे }\end{array}$ & $\begin{array}{l}\stackrel{0}{ } \\
\infty \\
\infty \\
\infty \\
\llcorner\end{array}$ & $\begin{array}{l}\stackrel{\circ}{+} \\
\stackrel{+}{+} \\
\dot{0}\end{array}$ & $\begin{array}{l}\stackrel{\circ}{\circ} \\
\text { ஸे } \\
\text { ஸे }\end{array}$ \\
\hline $\mid$ & 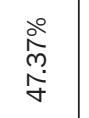 & 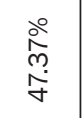 & $\begin{array}{l}\text { ळें } \\
\text { రิ } \\
\text { ஸु }\end{array}$ & $\begin{array}{l}\text { ळे } \\
\text { ஸे } \\
\text { ஸึ }\end{array}$ & $\begin{array}{l}\text { ळे } \\
\infty \\
\text { ஸ் }\end{array}$ & 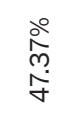 & 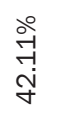 & 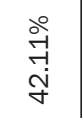 & $\begin{array}{l}\stackrel{\circ}{\grave{9}} \\
\stackrel{\rho}{\sim} \\
\stackrel{f}{*}\end{array}$ & $\begin{array}{l}\text { ஷें } \\
\text { ஸे } \\
\text { ஸे }\end{array}$ & $\begin{array}{l}\stackrel{\circ}{\grave{\hat{N}}} \\
\stackrel{\sim}{\sim}\end{array}$ & 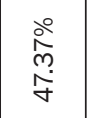 & 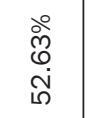 & 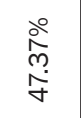 & $\begin{array}{l}\text { ळे } \\
\text { రิ } \\
\text { กิ }\end{array}$ & $\begin{array}{l}\stackrel{\circ}{\circ} \\
\infty \\
\stackrel{0}{\circ}\end{array}$ & 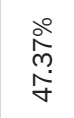 \\
\hline 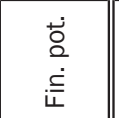 & $\begin{array}{l}\stackrel{\circ}{\circ} \\
\stackrel{\circ}{0} \\
i \\
\llcorner\end{array}$ & 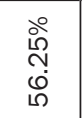 & 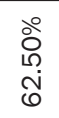 & $\begin{array}{l}\text { ठें } \\
\text { ஸे } \\
\text { రे }\end{array}$ & $\begin{array}{l}\stackrel{\circ}{\circ} \\
\stackrel{\circ}{\infty} \\
0 \\
0\end{array}$ & 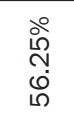 & $\begin{array}{l}\text { oे } \\
8 \\
\circ \\
\text { in }\end{array}$ & 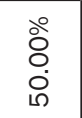 & 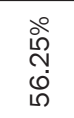 & 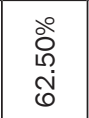 & 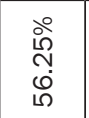 & 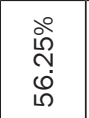 & 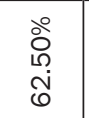 & 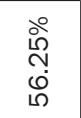 & 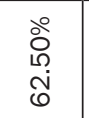 & $\begin{array}{l}\stackrel{0}{\circ} \\
\stackrel{\circ}{\circ} \\
\infty \\
0 \\
0\end{array}$ & 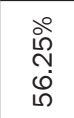 \\
\hline 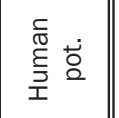 & $\begin{array}{l}\text { oे } \\
\text { : } \\
\text { i }\end{array}$ & $\begin{array}{l}\text { ○ें } \\
\text { ठें }\end{array}$ & $\begin{array}{l}\text { ○े } \\
\text { مी } \\
\stackrel{\circ}{\circ}\end{array}$ & 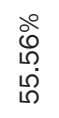 & $\begin{array}{l}\text { नें } \\
\text { नें } \\
\text { (1) }\end{array}$ & $\begin{array}{l}\text { ○ें } \\
\text { ठุ. }\end{array}$ & $\begin{array}{l}\stackrel{\circ}{\stackrel{\circ}{f}} \\
\stackrel{f}{+}\end{array}$ & $\begin{array}{l}\stackrel{\circ}{+} \\
\stackrel{\forall}{+}\end{array}$ & $\begin{array}{l}\circ \\
\text { ठ̊․ } \\
\circ \\
\circ\end{array}$ & 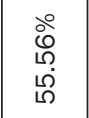 & $\begin{array}{l}\text { ठे } \\
\text { ठें }\end{array}$ & $\begin{array}{l}\text { ○े } \\
\text { ठ̀. } \\
\text { in }\end{array}$ & 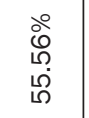 & 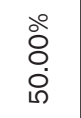 & 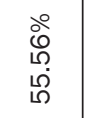 & $\begin{array}{l}\stackrel{\circ}{7} \\
\stackrel{-}{-1}\end{array}$ & $\begin{array}{l}\circ \\
\text { ठ̊. } \\
\text { ○े }\end{array}$ \\
\hline 吾䓂 & 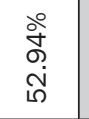 & 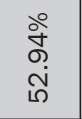 & $\begin{array}{l}\text { ○ें } \\
\infty \\
\infty \\
\infty \\
\infty\end{array}$ & $\begin{array}{l}\stackrel{0}{ } \\
\infty \\
\infty \\
\infty \\
\infty\end{array}$ & $\begin{array}{l}\stackrel{\circ}{~} \\
\stackrel{+}{0} \\
\dot{0}\end{array}$ & 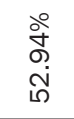 & 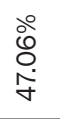 & $\begin{array}{l}\stackrel{\circ}{\circ} \\
\stackrel{\leftrightarrow}{\dot{f}}\end{array}$ & 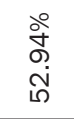 & $\begin{array}{l}\text { 今े } \\
\infty \\
\infty \\
\infty \\
\infty\end{array}$ & 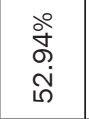 & 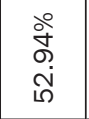 & $\begin{array}{l}\text { 今े } \\
\infty \\
\infty \\
\infty \\
\infty\end{array}$ & 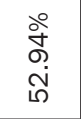 & 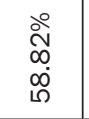 & 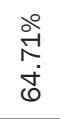 & 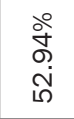 \\
\hline 䇏焉 & $\begin{array}{l}\stackrel{\circ}{\circ} \\
\stackrel{\text { N }}{\circ} \\
\stackrel{\circ}{0}\end{array}$ & $\begin{array}{l}\stackrel{\circ}{\circ} \\
\stackrel{2}{N} \\
\stackrel{6}{\circ}\end{array}$ & $\begin{array}{l}\text { ठें } \\
\text { ஸं } \\
\text { రิ }\end{array}$ & 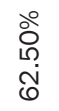 & $\begin{array}{l}\stackrel{\circ}{\circ} \\
\stackrel{1}{\alpha} \\
\infty \\
0\end{array}$ & 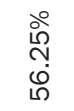 & 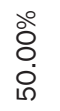 & $\begin{array}{l}\text { oे } \\
\text { ¿ें }\end{array}$ & $\begin{array}{l}\stackrel{\circ}{ } \\
\stackrel{\circ}{N} \\
\stackrel{\circ}{\circ}\end{array}$ & $\begin{array}{l}\text { ठे } \\
\text { م્ } \\
\text { } \\
0\end{array}$ & $\begin{array}{l}\stackrel{\circ}{\circ} \\
\stackrel{1}{0} \\
\stackrel{0}{\circ}\end{array}$ & $\begin{array}{l}\stackrel{\circ}{\circ} \\
\stackrel{1}{N} \\
\stackrel{0}{0} \\
\stackrel{n}{n}\end{array}$ & $\begin{array}{l}\text { ठें } \\
\text { م્ } \\
\text { రे }\end{array}$ & 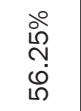 & $\begin{array}{l}\text { ठे } \\
\text { مึ } \\
\text { } \\
0\end{array}$ & $\begin{array}{l}\stackrel{\circ}{\circ} \\
\stackrel{2}{\circ} \\
\infty \\
0\end{array}$ & 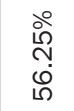 \\
\hline & 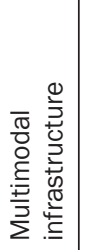 & 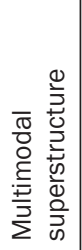 & 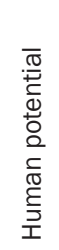 & 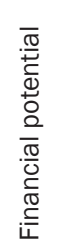 & 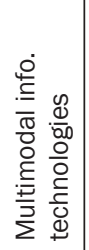 & 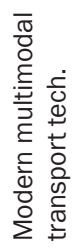 & 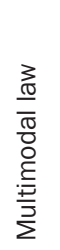 & 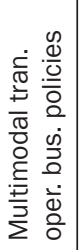 & 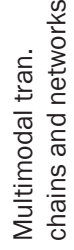 & 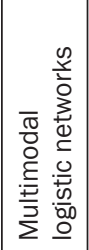 & 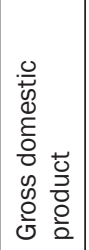 & 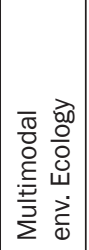 & 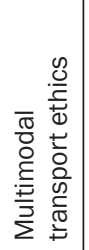 & 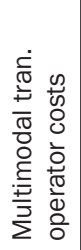 & 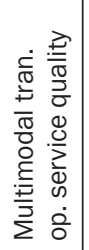 & 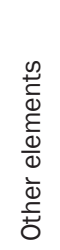 & 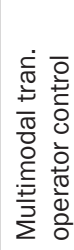 \\
\hline
\end{tabular}




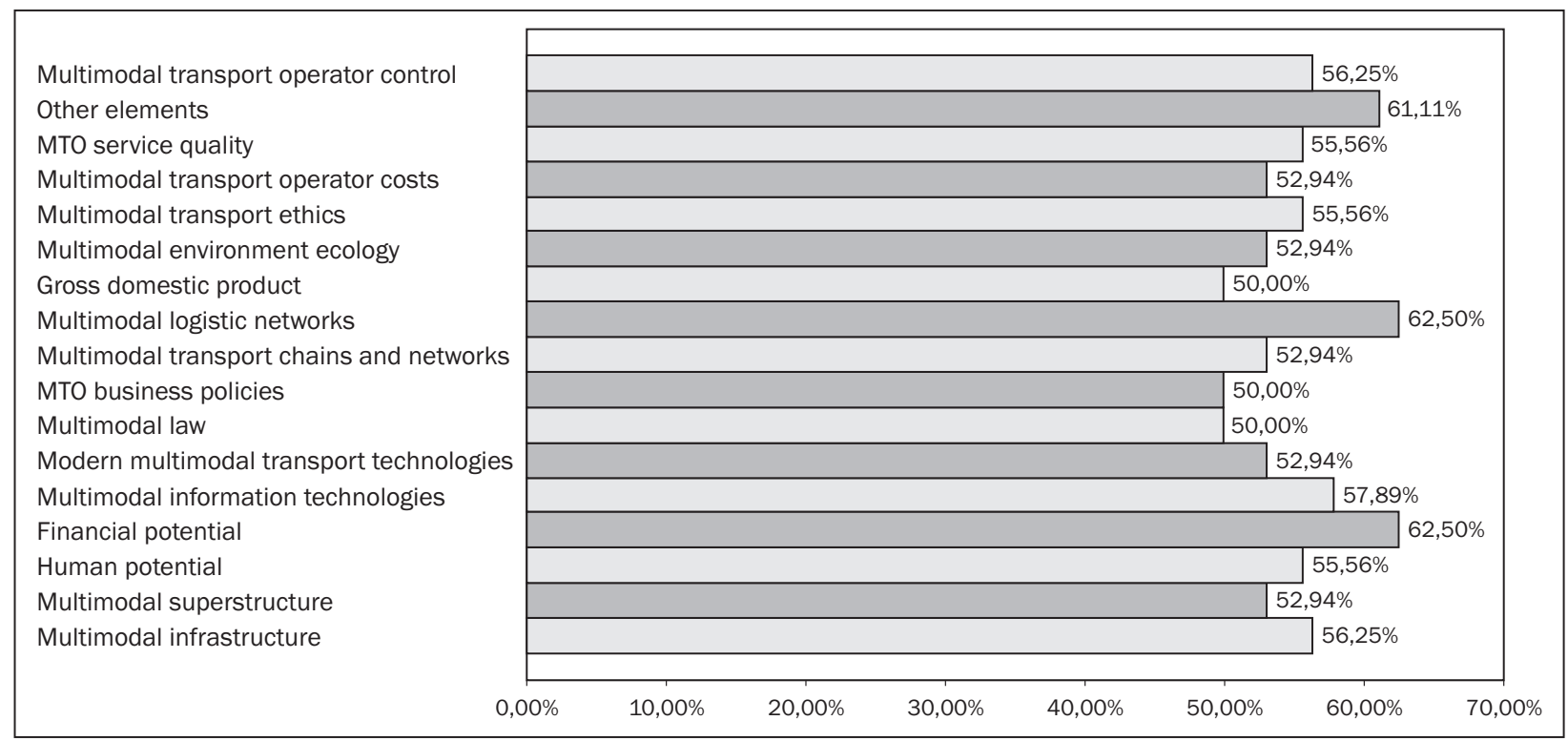

Graph 1 - Direct levels of growth of the liability insurance model

said element. Such synergetic requires indirect level of growth of the model elements, such as:

The indirect levels of growth of 5 elements of the model: human potential, financial potential, multimodal logistic networks, multimodal transport ethics and the service quality, can show similarities in their indirect growth levels, in relation to other elements (Graph 2). The indirect growth levels for the period until 2025 expect a growth of $62.50 \%$ in relation to the multimodal infrastructure, multimodal intellectual capital, the business policies, the multimodal law and the MTO control. The indirect growth levels of these elements are expected to rise as well, specifically to $58.82 \%$, in relation to the multimodal superstructure, modern multimodal technologies, multimodal transport chains and networks, multimodal ecology and MTO costs. Meanwhile, the indirect growth levels of these elements in relation to the gross domestic product and other elements expect a growth of $55.56 \%$, but only $52.63 \%$ in relation to the information technologies. When compared one to another, the indirect level of growth is $55.56 \%$, except in relation to the financial potential and multimodal logistic networks.

Further analysis of the indirect growth levels of the other elements of the liability insurance model shows, that in the period between 2009 and 2025, the relation between human potential, GDP, MTO ethics, MTO service quality and other elements shows similarities in their growth levels (Graph 3). The indirect growth level of other elements in relation to the above-men-

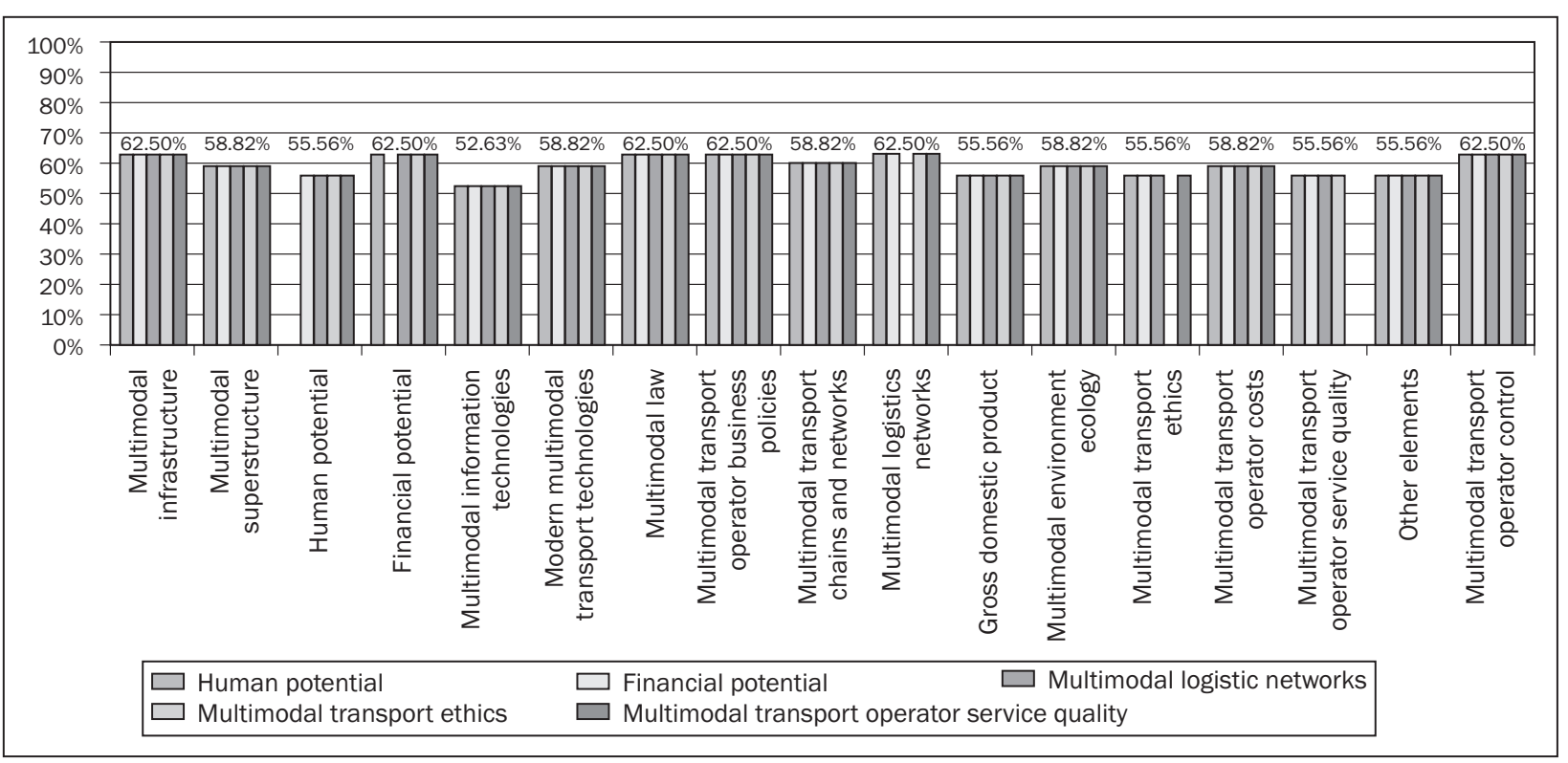

Graph 2 - Indirect levels of growth of the human potential, financial potential, multimodal logistic networks, MTO ethics and MTO service quality in relation to other elements of the model 


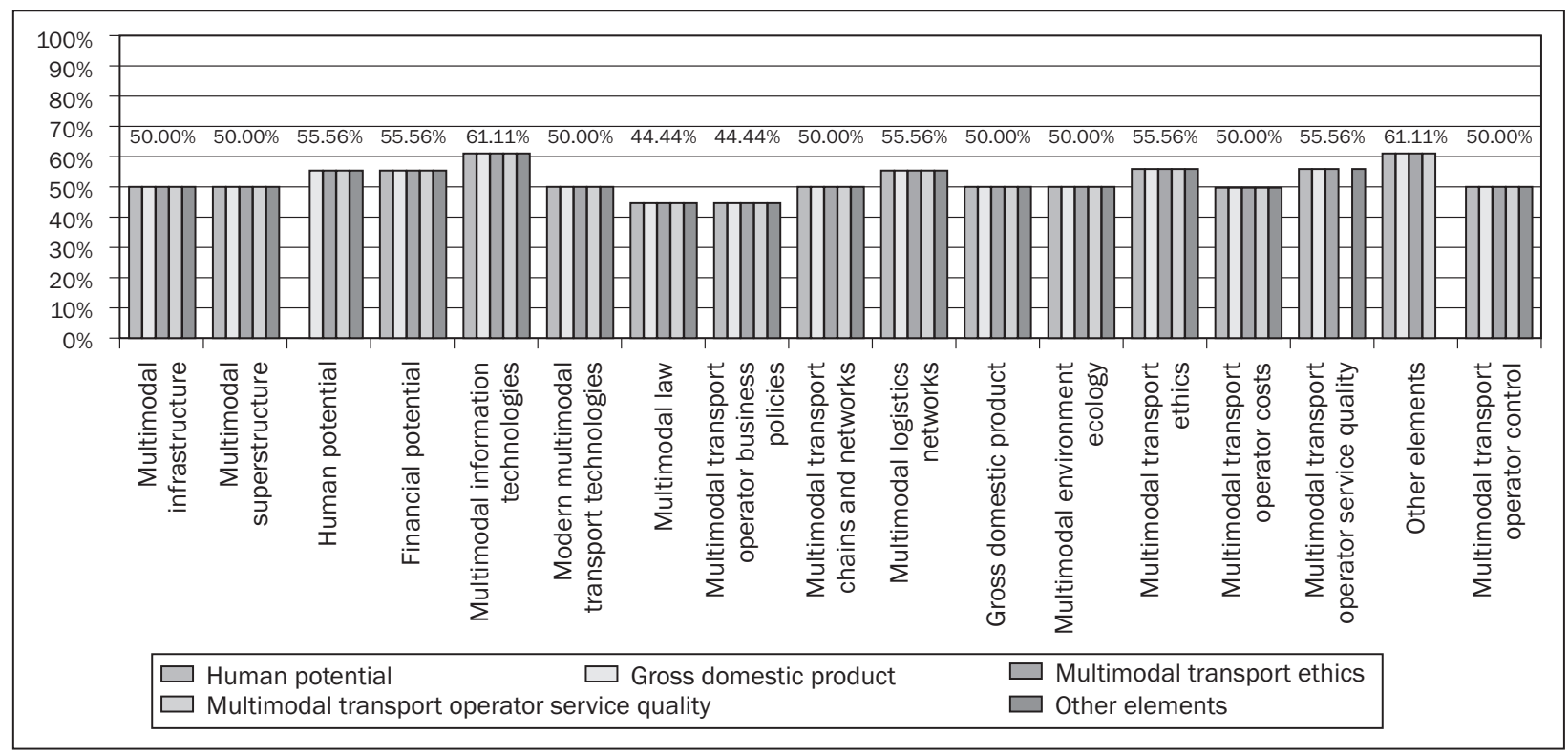

Graph 3 - Indirect growth levels of other elements in relation to the human potential, $G D P$, ethics, service quality and other elements

tioned elements represents the growth of the business policies of the MTO and the MTO law for $44.44 \%$. Other than that, the multimodal infrastructure, superstructure, intellectual capital, multimodal transport chains and networks, the ecology, costs and control of the MTO have grown by $50.00 \%$ in relation to the previously mentioned elements. The financial potential and multimodal logistics networks elements are expected to grow by $55.56 \%$ as well, in relation to the human potential, GDP, ethics, service quality and other elements. In the period between 2009 and 2025, information technologies are expected to see the highest growth, reaching $61.11 \%$.

It can be further seen from Graph 3 that the MTO ethics and service quality expect to see a $55.56 \%$ indirect growth, 50.00\% for GDP and 55.56\% in relation to the human potential. The reverse is true for MTO ethics and service quality. It can also be seen that the human potential, ethics and MTO service quality is expected to grow by $55.66 \%$, other elements by $61.11 \%$ in relation to the GDP. The growth of the human potential, ethics and service quality is $55.66 \%, 50.00 \%$ for GDP in relation to other elements.

\subsection{Multimodal transport operator liability insurance model testing}

Testing of the model is based on research vision. On a sample of 50 employees in 3 major logistics companies, 6 forwarding companies, 5 insurance companies and 4 companies for import, export and transit. The questions of research are: is the development of multimodal transport operator liability insurance a positive decision, can those elements develop and evaluate multimodal transport operator liability insur- ance model and whether measured values for the model are in accordance with the results of respondents in the various structures and areas of work. The results of research help to determine the direct usability value of the model universality.

Statistical analysis of the gathered data is achieved by using the arithmetic mean $\bar{x}$ for years 2009, 2015 and 2025 . The data used is based on the representative sample.

$$
\begin{gathered}
\bar{x}=\left(\frac{n_{1} \times x_{1}+n_{2} \times x_{2}+n_{3} \times x_{3}+\ldots+n_{m} \times x_{m}}{n_{1}+n_{2}+n_{3}+\ldots+n_{m}}\right) \times 10 \\
n=1 \ldots 25 ; x=1 . .100
\end{gathered}
$$

The analysis of the collected values shows that the people we surveyed agree with the proposed values. As a result, it would be wise to plan reform and development activities of those segments that will be part of the model function, which would reinforce the proposal and its efficient risk coverage.

\subsection{Multimodal transport operator liability insurance terms proposal}

The proposal of the liability insurance terms defines the elements which generally dictate the insurance relationship between the insurer and the insured party, taking into account the insurance liability of the carriers in each primary transit branch. The rest of the terms or more commonly called the special terms of the liability insurance define the contents of this insurance in greater detail, which differ from other insurances. Among the differences there is: the object of insurance, the insurance coverage, liability assessment, insurance premium, insurance claim documentation and indemnity height. 
Table 2 - Arithmetic mean of the survey results

\begin{tabular}{|c|l|c|c|c|}
\hline \multirow{2}{*}{ Serial No. Elements } & \multicolumn{3}{|c|}{ Arithmetic mean } \\
\cline { 3 - 5 } & & 2009 & 2015 & 2025 \\
\hline 1 & Multimodal infrastructure & 35.2 & 49.6 & 79.2 \\
\hline 2 & Multimodal superstructure & 41.2 & 47.2 & 84.8 \\
\hline 3 & Human potential & 39.2 & 61.2 & 88.8 \\
\hline 4 & Financial potential & 30.8 & 48.8 & 79.6 \\
\hline 5 & Multimodal information technologies & 41.6 & 54.8 & 93.6 \\
\hline 6 & Modern multimodal technologies & 38.4 & 46.8 & 86.0 \\
\hline 7 & Multimodal law & 38.3 & 42.4 & 78.8 \\
\hline 8 & MTO business policies & 38.0 & 42.8 & 78.8 \\
\hline 9 & MT chains and networks & 40.4 & 46.8 & 85.6 \\
\hline 10 & Multimodal logistics networks & 31.6 & 45.4 & 79.2 \\
\hline 11 & GDP & 44.4 & 45.6 & 88.4 \\
\hline 12 & MTO ecology & 40.0 & 46.8 & 85.2 \\
\hline 13 & MT ethics & 41.2 & 50.4 & 88.8 \\
\hline 14 & MTO costs & 39.6 & 46.8 & 86.4 \\
\hline 15 & MTO service quality & 39.6 & 50.0 & 88.4 \\
\hline 16 & Other elements & 41.6 & 56.0 & 88.8 \\
\hline 17 & MTO control & 34.8 & 44.4 & 80.0 \\
\hline
\end{tabular}

\section{CONCLUSION}

Based on the findings of the lacking legal regulations and the fact that the liability insurance for an MTO protects the operator from legal liability on individual branches of the transport only if he is a carrier or he must get a regress right from the contractor of the transportation part, full covering insurance represents a challenge in the shape of a universal insurance model. It should at the same time positively affect the level, security and rationality of the process in the multimodal transport system. To achieve this goal, we set, evaluated and analyzed the elements for the model universality and with the help of the grown matrix proposed a growth and development model for liability insurance. We analyzed the state in 2009 and the expectations in 2015 and 2025 which are supposed to bring improvements in legal aspects, the activity field and general economic growth.

The research and analysis conducted makes it clear that:

- direct growth levels concerning the individual element growth independently of others are between $52.94 \%$ and $62.50 \%$,
- indirect growth levels which reflect the growth structure of the element via the growth matrix in the entire system are between $44.44 \%$ and $68.75 \%$.

The direct and indirect growth levels coupled with the individual and synergetic effects enable us to suppose a certain development of the liability insurance model for an MTO in its wholeness, but there are many conditions that need to be met within the individual elements themselves. Creating the legal, economic and social conditions, the financial and human motivation potential, investment in the infrastructure, superstructure and other fields of business with the goal to improve the quality of MTO service are just some of the numerous conditions, preventing the operator as well as the insurance company to be interested in the liability insurance for an MTO. In correlation with these findings we find ourselves with an affirmed proposal of the liability insurance terms which are acceptable both for the insurance company (mainly focused on the insurance premium), the multimodal transport operator (mainly focused on the insurance coverage) and the multimodal service customers (mainly focused on the risk of doing business with an MTO). 


\section{Dr. SC. RATKO ZELENIKA}

E-mail: ratko.zelenika@uni-mb.si

Univerza v Mariboru, Fakulteta za gradbeništvo

Smetanova ulica 17, 2000 Maribor, Slovenija

Mr. sc. TOMAŽ LOTRIČ

E-mail: tomazlotric@yahoo.com

Združenje šoferjev in avtomehanikov Celje

Slomškov trg 1, 3000 Celje, Slovenija

ERVIN BUŽAN

E-mail: ervin.buzan@siol.net

Gažon 37a, 6274 Šmarje, Slovenija

\section{POVZETEK}

\section{MODEL ZAVAROVANJA ODGOVORNOSTI OPERATORJA MULTIMODALNEGA TRANSPORTA}

Multimodalni transport predstavlja transport blaga od mesta, kjer je operator multimodalnega transporta prevzel blago za transport pa vse do mesta predaje blaga, z uporabo najmanj dveh različnih načinov transporta, na osnovi ene pogodbe o multimodalnem transportu in enega dokumenta, ne glede na vrsto in število uporabljenih prevoznih sredstev. Ključni faktor optimalnega funkcioniranja multimodalnega transporta predstavlja operator multimodalnega transporta. Ta mora, zaradi spleta nepredvidljivih okoliščin, zapletenosti poslovnih procesov, muhavosti narave in nepazljivosti, dobro organizirati in izvrševati multimodalni transport na vseh nivojih.

Zaradi omenjenih nevarnosti in dejstvu, da se še vedno ne posveča dovolj pozornosti obvladovanju in strategiji zavarovanja odgovornosti operatorju $v$ multimodalnem transportu, ki bi skozi pregled obstoječe ureditve multimodalnega transporta z eno samo zavarovalno pogodbo krile vse vrste transporta in spremljajoče dejavnosti odgovornosti operatora multimodalnega transporta, se $v$ tem članku poraja potreba, da predlagamo model zavarovanja odgovornosti operatorja multimodalnega transporta.

Model zavarovanja odgovornosti operatorja multimodalnega transporta zajema 17 elementov in vse vrednosti, s katerimi se kvantificirajo elementi zavarovanja v letu 2009 kot tudi predpostavljene vrednosti v letu 2015, ko se pričakuje napredek $v$ implementaciji projektov ekonomskega procesa razvoja tranzicije ter vrednosti v letu 2025, ki bi predstavljale obdobje inovacij, rekonstrukcij, optimizacij in modernizacij.

$S$ predpostavljenim modelom za zavarovanje odgovornosti operatora multimodalnega transporta je dana osnova za zavarovanje odgovornosti, ki bi ga koristil operator multimodalnega transporta.

\section{KLUČNE BESEDE}

transportno zavarovanje, multimodalni transport, operator multimodalnega transporta in sistem odgovornosti operatorja multimodalnega transporta

\section{LITERATURE}

[1] Clarke, M.A.: International Carriage of Goods by Road, Sweet \&Maxwell, London , 1997.

[2] Ostergard, S.: Multimodal and Interoperable transport Standardisation, The Danisch Technological Institute, Dansk Standard, 1999

[3] Pavliha, M., Vlačič, P.: Prevozno pravo, GV Založba Ljubljana, Ljubljana, 2007

[4] Stojanović, D.: Ekonomsko -matematički metodi i modeli, Ekonomska fakulteta Univerze $v$ Beogradu, Belgrade, 1990, p. 481

[5] Zelenika, R.: Multimodalni prometni sustavi, Ekonomski fakultet u Rijeci, Rijeka, 2006

[6] Zelenika, R.: Pravo multimodalnoga prometa, Ekonomski fakultet Sveučilišta u Rijeci, 2006

[7] Poletan Jugović, T., Jugović, R., Zelenika, R.: Multicriteria Optimisation in Logistics Forwarder Activities, PROMET - Traffic\&Transportation No.3, Zagreb, 2007

[8] Zebec, S., Zelenika, R., Zečević, S.: Measuring the Intellectual Capital of International Carriers as Logistics Operators, PROMET - Traffic\&Transportation No.2, Zagreb, 2007.

[9] Zelenika, R., Vukmirović, S., Mujić, H.: Computer- Supported Modelling of Multimodal Transportation Networks Rationalization, PROMET-Traffic\&Transportation No.5, Zagreb, 2007.

[10] Obligacijski zakonik, Uradni list RS, No. 40/07.

[11] Pomorski zakonik, Uradni list RS, 120/06.

[12] Zakon o plovbi po celinskih vodah, Uradni list RS, št. 30/02.

[13] Zakon o prevoznih pogodbah $v$ cestnem prometu, Uradni list RS, št. 126/03, 102/07.

[14] Zakon o prevozih $v$ cestnem prometu, Uradni list RS, št. 131/06.

[15] Zakon o prevoznih pogodbah v železniškem prometu, Uradni list RS, št. 61/00. 